\title{
Food for thought - examining farmers' willingness to engage in conservation stewardship around a protected area in central India
}

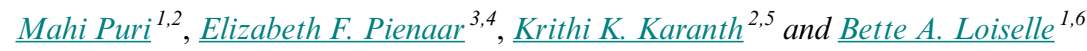

\begin{abstract}
Although protected areas (PAs) have long been considered a successful conservation strategy, more recent research has highlighted their ecological and sociological limitations. The extant PA network is constrained by land availability and exacerbates cultural, political, and social conflicts over access to resources. Consequently, the importance of private lands in playing a complementary role in conservation is being widely recognized. Voluntary conservation programs that encourage private landowners to adopt biodiversity-friendly agricultural practices have emerged worldwide. Landowners' willingness to participate in these programs is critical to attaining landscape-level biodiversity conservation. We adopted a multidisciplinary approach, combining economic theory of rational choice and social choice theory to explain decision making. Using a stated preference choice experiment method, we examined the role of program design and influence of demographic, economic, and socio-psychological variables on landowners' willingness to enroll in voluntary, incentive-based agroforestry programs. In 2018-2019, we surveyed 602 landowners in the buffer area of Pench Tiger Reserve, India. Landowners' willingness to engage in agroforestry depended on the amount of land to be enrolled, program duration, and incentive amount. Landowners' socio-economic characteristics, attitudes, self-efficacy, and social norms also influenced their willingness to participate. On average, landowners required Rs. 66,000 (ca. \$940 USD) per acre per year to modify their land use and adopt agroforestry. Our study demonstrates that integrating voluntary agroforestry programs into India's rural development policy may allow biodiversity conservation to be balanced with agricultural productivity in buffer areas surrounding PAs. We call for a new approach that recognizes farmers as stakeholders in conservation and in creating resilient landscapes that support biodiversity and preserve livelihoods.
\end{abstract}

Key Words: agroforestry; incentives; land sharing; private land; stated preference choice experiment; wildlife conservation

\section{INTRODUCTION}

Conservation approaches and the context for framing peoplenature relationships are evolving (Mace 2014). Although people have long assumed that protected areas ${ }^{1}$ (PAs) are a successful strategy for conserving the world's biodiversity and buffering against climate change, water insecurity, and habitat destruction (Bruner et al. 2001), many now question the effectiveness of PAs in achieving those goals (Mammides 2020). Although it is true that a subset of PAs encompass biologically important ecosystems to safeguard them from spatial and temporal threats (Andam et al. 2008), the inadequate size, isolation, fragmentation, and suboptimal levels of species diversity of many PAs (IUCN categories I-II) constrain their ecological effectiveness (DeFries et al. 2005). Studies show that the extant PA network, constrained by the availability of land (Foley et al. 2005), is limited in its capacity to meet conservation goals (Mora and Sale 2011). The ranges of several species of conservation concern overlap, at least in part, with human-dominated areas under private ownership (Chapron et al.2014). From a sociological perspective, researchers have criticized the exclusionary approach used to create inviolate PAs, which ignores the livelihoods of people who live in surrounding areas, including their income security, access to resources, and conflicts with wildlife (Naughton-Treves et al. 2005, West et al. 2006). To secure both biodiversity conservation and social welfare, researchers have advocated for more voluntary and participatory management of natural resources that includes local people in the decision-making process (Redpath et al. 2017).
Private lands play a critical, complementary role in biodiversity conservation at the landscape level (Kamal et al. 2015). Accordingly, land acquisition and purchase have been regarded as a potential approach to enhance the conservation effectiveness of PAs by preventing land conversion to uses that do not support conservation (McDonald-Madden et al. 2008). However, this strategy is susceptible to criticisms of land grabbing and displacement of communities (Ojeda 2012). Innovative approaches that encourage voluntary conservation on private lands have thus emerged in Europe and North America in the form of land trusts, conservation easements, mitigation banking, and cost-share conservation programs (Merenlender et al. 2004). Similarly, programs such as Socio Bosque in Ecuador and Grainto-Green in China incentivize ecological restoration on private lands (Chen et al. 2009, de Koning et al. 2011).

Voluntary conservation initiatives on private lands focus on restoring the ecological integrity of agricultural or modified landscapes. Natural regeneration is a slow process, with native species sometimes taking decades to recolonize (Flinn and Vellend 2005). Recovery of degraded or damaged ecosystems can be accelerated through assisted regeneration coupled with intensive management (Chazdon 2017). Adoption of integrated land-use systems, such as agroforestry, to create mixed landscapes is fundamental to attaining restoration (Nair 2008). Agroforestry combines crop production with growing trees. The trees grown on an agroforestry landscape may support food production (directly by providing edible products and indirectly by enhancing

${ }^{1}$ Department of Wildlife Ecology and Conservation, University of Florida, Gainesville, Florida, USA, ${ }^{2}$ Centre for Wildlife Studies, Bengaluru, India, ${ }^{3}$ Warnell School of Forestry and Natural Resources, University of Georgia, Athens, Georgia, USA, ${ }^{4}$ Mammal Research Institute, University of Pretoria, Pretoria, South Africa, ${ }^{5}$ Nicholas School of the Environment, Duke University, Durham, North Carolina, USA, ${ }^{6}$ Center for Latin American Studies, University of Florida, Gainesville, Florida, USA 
Fig. 1. A theoretical framework classifying "program factors" and "farmer (landowner) characteristics." The latter include land characteristics, demographic, economic, and sociopsychological variables that can influence landowner preferences or willingness to participate in an incentive-based conservation program. Note: this is not an exhaustive list of variables, but a representative subset, some of which have been used in our study.

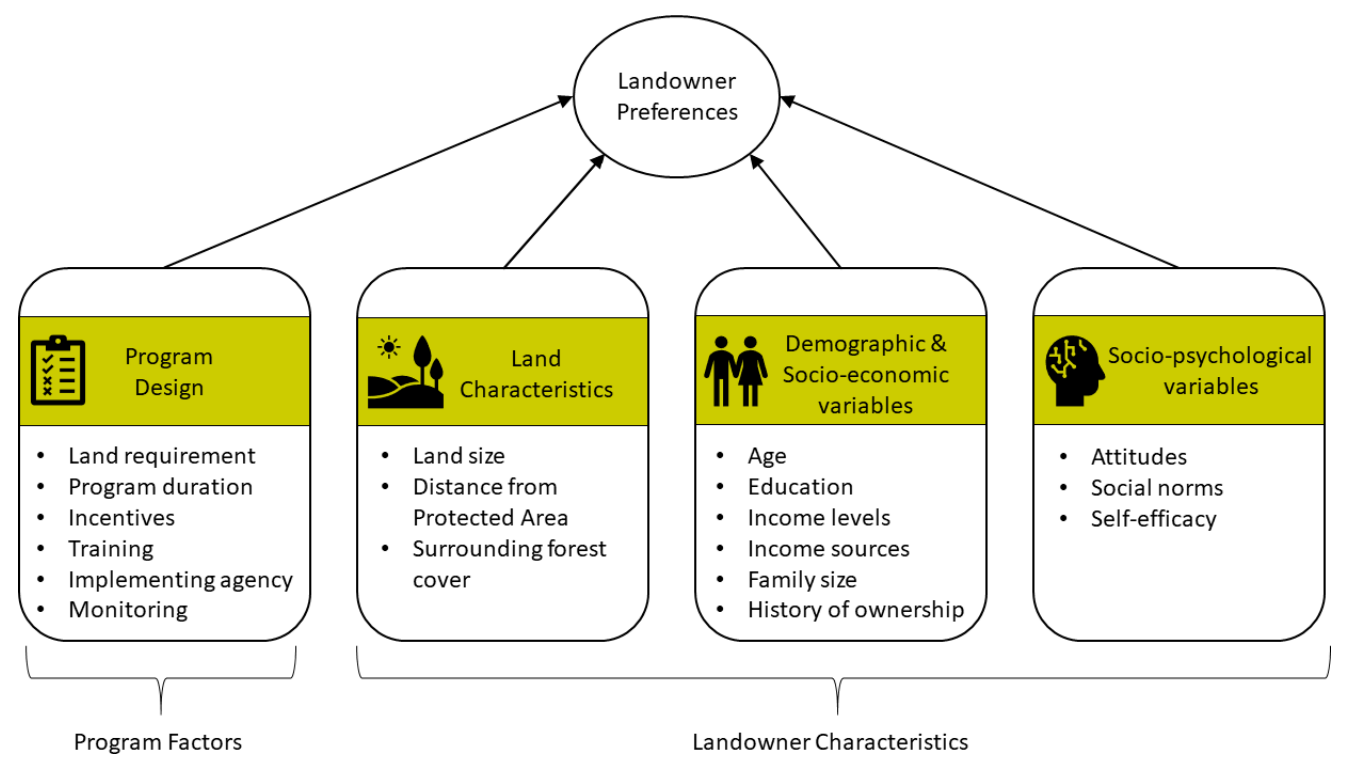

soil quality), generate materials for other economic uses (fodder, firewood, construction), and provide medicinal materials (Nair 2008). Voluntary agroforestry initiatives that result in integrated land-use systems align with the "land sharing" paradigm, thereby contributing to biodiversity conservation, maintaining connectivity across landscapes, and reducing pressures on PAs (Phalan et al. 2011, Sharma and Vetaas 2015).

Private lands conservation interventions such as agroforestry, however, may result in opportunity costs in the form of income foregone from alternative intensive land-use practices (Benjamin and Sauer 2019). Individual farmers (specifically landowners) may hamper conservation outcomes if their financial and social needs are not met (Knight et al. 2010). Furthermore, the effectiveness of voluntary conservation programs is contingent on landowners' willingness to participate in these programs (Conradie et al. 2013). Factors that influence landowners' willingness to engage in conservation programs include their landholdings (e.g., property rights, land tenure, farming practices), demographics (e.g., age, education, income), sociopsychological characteristics (e.g., self-efficacy, trust in government, conservation knowledge), and conservation program design (e.g., program structure and incentives offered; Fig. 1) (Pienaar et al. 2014, Lastra-Bravo et al. 2015, Deng et al. 2016, Lalani et al. 2016). Landowners' engagement in conservation programs may also be shaped by a history of peoplepark or people-wildlife conflicts, institutional support afforded to people, and the inclusiveness of the conservation decisionmaking process.

The need for private lands conservation programs and the challenges in effectively designing these programs are particularly relevant to India. India is a megadiverse country (Mittermeier et al. 2011) with over 800 PAs (IUCN categories II-VI) that have succumbed to the pressures that PAs face globally. The average size of India's PAs is less than $200 \mathrm{~km}^{2}$ (ENVIS Centre on Wildlife and Protected Areas 2019). They are highly fragmented with limited connectivity and are under severe development pressure. Protected Areas in India are surrounded by high densities of humans and livestock. Unsustainable resource use contributes to forest degradation and negatively impacts wildlife populations (Margulies and Karanth 2018, Li et al. 2020). Local communities resent the State and conservation agencies because they are often excluded from decision making, their rights over forests are suspended, and their access to resources is limited (Kashwan 2016). As a result, alternative conservation strategies that complement the conservation value of PAs and focus on local involvement in decision making, including adoption of biodiversity-friendly agriculture and ecotourism, are gaining traction in India (Sinha et al. 2012, Ramalingam and Dharma Rajan 2015).

Within India, a voluntary incentive-based private lands conservation program has not been tested. Similarly, there is a lack of science-based knowledge of the factors that facilitate or inhibit conservation stewardship by rural communities. To address these research gaps, we designed a study to identify how landowners' willingness to engage in agroforestry programs are influenced by (1) program design, (2) the demographic and economic characteristics of landowners, and (3) the sociopsychological characteristics of landowners. Understanding barriers to and motives for participation in private lands conservation programs is necessary to improve the effectiveness of these programs, enhance landowner participation, and engender partnerships between local stakeholders. 


\section{METHODS}

\section{Study area}

We conducted our study in the administrative buffer of Pench National Park and Tiger Reserve (PTR) in Madhya Pradesh, India (Fig. 2). The PTR covers an area of $1179.6 \mathrm{~km}^{2}$ divided between a core area $\left(411.3 \mathrm{~km}^{2}\right)$ and a buffer zone $\left(768.3 \mathrm{~km}^{2}\right)$. It is an integral component of the central India tiger (Panthera tigris tigris) landscape and supports tigers and a diverse assemblage of other carnivores such as leopards (Panthera pardus), sloth bears (Melursus ursinus), wild dogs (Cuon alpinus), herbivores including chital (Axis axis), sambar (Rusa unicolor), nilgai (Boselaphus tragocamelus), wild boar (Sus scrofa), and primates (Menon 2014). The core area is inviolate, with no human habitation, resource extraction, or agriculture permitted. Regulated economic activities (primarily agriculture) are permitted in the buffer zone. A national highway cuts across the region.

Fig. 2. Map of the Pench Tiger Reserve (PTR), delineating the core area and the buffer area. The farmer surveys $(n=602)$ were conducted in $500 \mathrm{~km}^{2}$ of buffer area to the west of the national highway. Surveys were distributed uniformly across the four administrative ranges and in proportion to village population. Inset: location of PTR in the State of Madhya Pradesh, India.

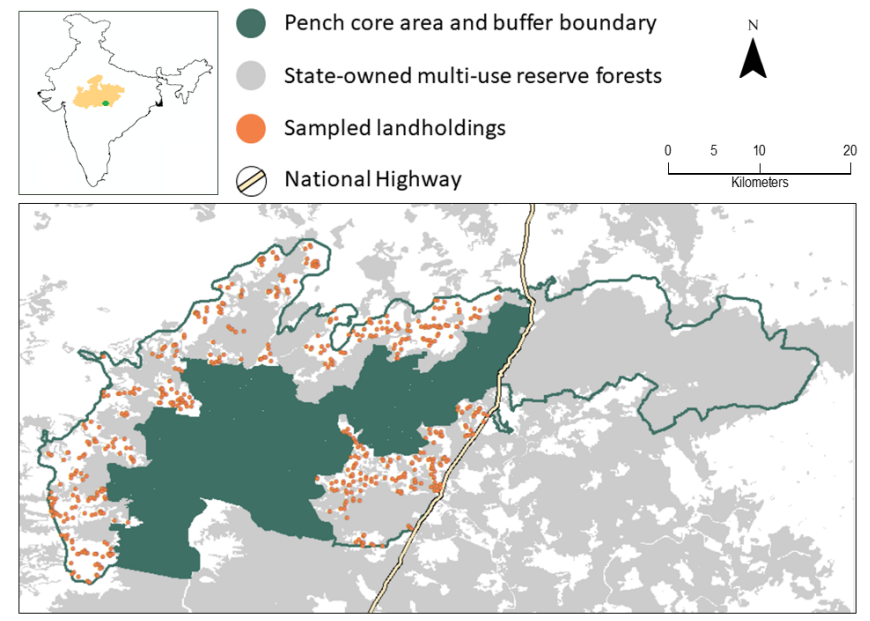

We focused our study to the west of the highway covering approximately $500 \mathrm{~km}^{2}$. There are 95 villages located within this area, with nearly 15,000 households. The landscape is composed of multi-use reserved forests, state-owned timber plantations, and privately owned agricultural areas. The reserved forests are used by people to graze livestock and collect firewood, fodder, and nontimber forest products (NTFPs). Agriculture forms the backbone of the local economy. The primary crops grown include wheat, rice, maize, sugarcane, pulses, and oilseeds. Agricultural incomes are supplemented with animal husbandry and dairy farming, sale of NTFPs, and other service jobs provided by the government and tourism sectors. Local communities include people belonging to Scheduled Tribes ${ }^{2}$ (ST), Scheduled Castes (SC), Other Backward Classes (OBC), and General category. With high overlap between people and wildlife, negative interactions- including livestock depredation by carnivores and crop raiding by herbivores - are common, resulting in economic and psychological costs.

\section{Study design}

We aimed to survey a minimum of 400 households (population of 15,000 households) to achieve statistically significant results (with 5\% margin of error and 95\% CI; Cochran 1977). We sampled a minimum of three households in villages with less than 100 households. We proportionally increased the number of households surveyed based on village size. We contacted representatives from local farmers' associations to obtain lists of landowners (household heads) in their village. A team of two to three enumerators (individuals who implemented the questionnaires) administered questionnaires in-person to the head of the household or the main land management decision maker in the family. Every survey team included at least one local community member to secure the trust of respondents, which was critical to ensure research participation and honest answers. We rigorously trained the enumerators and pre-tested the questionnaires with $35 \mathrm{key}$ informants to mitigate response biases (e.g., strategic responses that do not reflect the true preferences of research participants). We administered questionnaires from November 2018 to March 2019 in the local Hindi language. We obtained respondents' informed oral consent before conducting any surveys.

The questionnaire included stated preference choice experiments (SPCEs; Hensher et al. 2005), which we designed to ascertain respondents' willingness to engage in agroforestry in return for annual payments. Economists use SPCEs to elicit the value that respondents place on different features (attributes) of a conservation program, and the type and amount of payment required by potential participants to enroll in the program (Pienaar et al. 2014). Stated preference choice experiments reveal expected levels of program participation (Adams et al. 2014) and which characteristics of respondents influence their willingness to participate (Harihar et al. 2015).

We designed a multi-profile SPCE, wherein respondents chose among two profiles (or programs) with differing attribute ${ }^{3}$ levels. Based on existing literature, we included three attributes in the SPCEs, namely "LAND" (the percentage of land to be allocated to agroforestry), "YEARS" (the number of years of program enrollment), and "PAYMENT" (the amount of payment provided per acre of land per year) (Ruto and Garrod 2009, Scriven 2012; Table 1). Nearly 55,000 acres of land in the study area are under private agriculture. As the percentage of land to be enrolled by landowners is a basic unit for conservation program implementation and because it is directly linked to landowners' opportunity costs, we included "LAND" as our first attribute. Agroforestry and other land restoration efforts are long-term projects. Because such agroforestry initiatives have not been tested in the study area before, landowners may be concerned about enrolling in long-term, untested commitments. Accordingly, we included "YEARS" of program enrollment as our second attribute. The study area is drained by the Pench river and represents a relatively fertile region, allowing for higher agricultural incomes compared with other drier or raindependent regions. As such, we included "PAYMENT" to ascertain the monetary compensation required in our study area 
to encourage landowner participation in conservation programs, while still meeting the budget constraints of conservation agencies. The levels for each attribute were determined through key informant surveys while pre-testing the questionnaire. We selected only three attributes to limit cognitive load for respondents and reduce attribute non-attendance.

Table 1. Attributes and attribute levels for the stated preference choice experiment

\begin{tabular}{lc}
\hline \hline Attribute & Attribute Levels \\
\hline Percentage of land to be enrolled & $25 \%$ \\
& $50 \%$ \\
Number of years of enrollment & $75 \%$ \\
& 4 years \\
Payment amount per acre per year ${ }^{\dagger}$ & 8 years \\
& 12 years \\
& Rs. 45,000 \\
& Rs. 60,000 \\
& Rs. 75,000 \\
& Rs. 90,000 \\
\hline
\end{tabular}

${ }^{\dagger}$ Rs. - Indian Rupees (\$1 USD = Rs. 70 at the time of survey)

We implemented a balanced block design (Hensher et al. 2005) to reduce respondent fatigue. With 36 possible combinations (three land allocations $\mathrm{x}$ three program durations $\mathrm{x}$ four payment amounts), we generated three survey blocks, each with three choice experiments. We chose the design with the highest Defficiency ${ }^{4}$ of 97.19. Respondents selected one of two profiles or the option to "opt out" by remaining at status quo, i.e., they could choose not to enroll in any of the offered agroforestry programs (see Fig. 3 for an example of a choice experiment). We informed respondents that the agroforestry programs were hypothetical to avoid false expectations of receiving any monetary benefits. However, to avoid hypothetical bias ${ }^{5}$, we also informed respondents that their honest responses were important to guide the design of future conservation programs in the region. We provided a detailed description of which land management practices respondents would be expected to implement on enrolled lands, specifically, cultivation of fruiting trees, medicinal plants, and bamboo along with other crops. We used photographs (Append. 1: Fig. A1.1) as visual aids to help respondents understand how they would be expected to manage their land before selecting whether they would enroll in an agroforestry program.

In addition to the SPCEs, we collected demographic information (e.g., age, years of education, number of household members), economic information (e.g., size of agricultural landholdings, income from agricultural and non-agricultural sources, diversity in household income), and information on past interactions with wild animals. We also collected socio-psychological data using five-point Likert scale questions to measure respondents' attitudes toward modifying land uses (in terms of provision of resources, effort and expenditure required to implement alternative land uses, and consequent conflicts with wildlife), selfefficacy (confidence in their capabilities to meet program requirements, availability of land, access to irrigation, technical knowledge), and social norms (relating to family and other community members' support for enrolling in conservation programs). We included the Euclidean distance between each landholding and the PA boundary, and percentage of forest cover (measured using the land cover map developed by Roy et al. 2015 using medium-resolution IRS LISS-III images) within a $1-\mathrm{km}$ buffer of the landholding as additional variables. All demographic, economic, and socio-psychological variables are described in Table A1.1 (Append. 1). We tested for collinearity in explanatory variables prior to conducting regression analysis. Lastly, to delve deeper into other aspects of the rural economy, we collected ancillary data from survey respondents about rainfall trends, emigration, forest dependence, and perceptions about living close to a forest.

Fig. 3. An example choice experiment card used during the surveys in Pench Tiger Reserve, Madhya Pradesh. Each respondent was shown three such cards, with different program options and the option to opt out (i.e., stay at status quo). Note: Rs. - Indian Rupees ( $\$ 1$ USD = Rs. 70 at the time of survey).

\begin{tabular}{|c|c|c|c|}
\hline ATTRIBUTE & PROGRAM A & PROGRAM B & PROGRAM C \\
\hline $\begin{array}{l}\text { AREA TO BE } \\
\text { MODIFIED }\end{array}$ & & & \\
\hline $\begin{array}{c}\text { NUMBER OF } \\
\text { YEARS }\end{array}$ & 12 YEARS & 4 YEARS & \\
\hline $\begin{array}{l}\text { PAYMENT } \\
\text { AMOUNT } \\
\text { PER YEAR }\end{array}$ & Rs. 60,000 per acre & Rs. 90,000 per acre & \\
\hline
\end{tabular}

If you were given the above options, which program
would you like to choose? Circle one option
1. Program A
2. Program B
3. Program C (status quo)

\section{Analysis}

We first analyzed the SPCE data using multinomial logit models (MNL), the basic model for discrete choice modeling (Hensher et al. 2005). Economic theory assumes that all individuals act rationally by comparing program alternatives and choosing the alternative that generates the greatest level of satisfaction or utility (i.e., individuals maximize their utility). The overall utility that individual $i$ receives from each program (or choice profile) $j\left(U_{i j}\right)$ is a function of a systematic, observable component $\left(V_{i j}\right)$ and a random component $\left(\varepsilon_{\mathrm{ij}} ;\right.$ McFadden 1973):

$$
U_{i j}=V_{i j}+\varepsilon_{i j}=X_{i j}^{\prime} \beta+\varepsilon_{i j}
$$


where $\mathbf{X}_{\mathrm{ij}}$ is a vector of SPCE attribute levels for $\operatorname{program} j$ and $\beta$ is the vector of coefficients. Accordingly, $V_{i j}$ took the form:

$$
\begin{aligned}
V_{i j}= & \beta_{0}+\beta_{\mathrm{LAND}} \cdot \text { Land }_{i j}+\beta_{\mathrm{YEAR}} \cdot \text { Years }_{i j} \\
& +\beta_{\mathrm{PAY}} \cdot \text { Payment }_{i j}
\end{aligned}
$$

where "LAND" captured the percentage of land allocated to agroforestry $(25 \%, 50 \%, 75 \%)$, "YEARS" captured the duration of enrollment in the program (4, 8, 12 years), and "PAYMENT" captured the payment per acre per year (Rs. 45,000; Rs. 60,000; Rs. 75,000; Rs. 90,000) presented for $\operatorname{program} j$. Assuming that the error terms follow a type I extreme value distribution, the probability that individual $i$ chooses $\operatorname{program} j$ is given by:

$$
P_{i j}=\frac{\exp \left(\mathrm{X}_{\mathrm{ij}}^{\prime} \beta\right)}{\sum_{k \neq j} \exp \left(\mathrm{X}^{\prime}{ }_{\mathrm{ik}} \beta\right)}
$$

The basic multinomial logit model assumes homogeneity of preferences across individuals, which is highly unrealistic. Accordingly, we estimated a mixed logit (random parameters logit; RPL) model to test for heterogeneity of preferences across individuals, in order to better understand how respondents' willingness to engage in agroforestry programs is influenced by program design (research objective 1). In the RPL model, the coefficients $\beta_{i}$ vary across individuals, but are constant across each individual's choices (i.e., individuals are assumed to have stable preferences; see Nordén et al. 2017, Pienaar et al. 2019):

$$
P_{i j}=\frac{\exp \left(\mathrm{X}_{\mathrm{ij}}^{\prime} \beta_{\mathrm{i}}\right)}{\sum_{k \neq j} \exp \left(\mathrm{X}_{\mathrm{ik}}^{\prime} \beta_{\mathrm{i}}\right)}
$$

The vector of random parameters $\beta_{i}$ has a mean and variance, which captures heterogeneity of preferences across individuals. If the standard deviation coefficient for an attribute (or attribute level) is statistically significant, then this indicates that individuals are heterogeneous in their preferences for that attribute (or attribute level). We imposed a normal distribution on the $\beta$ parameters for LAND and YEARS and we assumed a fixed parameter estimate for PAYMENT ${ }^{6}$.

To test how landowners' willingness to engage in agroforestry programs is influenced by their demographic and economic characteristics and socio-psychological characteristics, we ran two sets of RPL models to assess these drivers of preference. In RPL model 1 (which was designed to address research objective 2), we included respondents' demographic and economic characteristics as shifters ${ }^{7}$ of the parameters for LAND and YEARS to test how these characteristics drive preferences for program design, specifically minimum land requirements to enroll in the program and duration of enrollment. In RPL model 2 (which was designed to address research objective 3), we interacted landowners' socio-psychological characteristics ${ }^{8}$ with the alternative specific constant ${ }^{9}$ (ASC), i.e., we included shifters for $\beta_{0}$ to test how respondents' socio-psychological characteristics influenced their decision to enroll in the conservation program. We selected the best fit models based on the lowest Akaike Information Criterion (AIC) (Burnham and Anderson 2002). We performed all analyses in NLOGIT version 6 using a maximum likelihood estimation procedure (Greene 2016).
Lastly, we calculated reservation payments required to enroll landowners in the conservation programs using the fixed parameter estimates from the best fit MNL model (Append. 1: Table A1.4) that included respondent characteristics:

$$
\text { reservation price }=-\frac{X_{i j}^{\prime} \beta}{\beta_{\mathrm{PAY}}}
$$

where $\beta_{\text {PAY }}$ is the coefficient on PAYMENT. The reservation payment is the minimum payment required by a respondent to engage in agroforestry. For derivation of the reservation payment, see the appendix.

\section{RESULTS}

\section{Demographic, economic, and socio-psychological characteristics} of households

We surveyed a total of 602 households (one person per household; 3-21 respondents per village based on the size of the village). We administered the questionnaires to household heads, who are often the decision makers (especially regarding land utilization). Nearly $98 \%$ of the survey respondents were male (Append. 1: Table A1.2). The average age of respondents was about 44 years (range: $19-80$ years), and approximately $53 \%$ of the respondents had less than 10 years of school education. The average size of households was five members, although we surveyed much larger joint families (range: 1-55 household members). The average landholding size was 11.3 acres (range: $2-90$ acres). On average, respondents grew three crops per year, consisting primarily of food crops such as wheat, rice, and maize. Respondents could not accurately calculate their agricultural profits because they found it difficult to estimate total labor and input costs. Instead, respondents provided their agricultural revenues (median $=\mathrm{ca}$. $\$ 2142$ USD per year). The majority $(85 \%)$ of households supplemented their incomes from an average of two other sources (see Append. 1: Table A1.2 for respondents' non-agricultural income sources and livestock ownership). See Append 1: Table A1.3 for respondents' perceptions of rainfall trends, forest dependence, benefits and disadvantages of living adjacent to forests, and emigration.

Negative interactions with wildlife can take the form of crop raiding by herbivores and carnivores preying on livestock or injuring and killing humans. When asked to name and rank the three most problematic wildlife species, approximately $32 \%$ of respondents listed only herbivores (highest conflict species: wild pig; $\mathrm{n}=539$ ) and $22 \%$ of respondents also listed primates, parakeets, snakes, and rodents (Append. 1: Table A1.2). Although $70 \%$ of respondents indicated that carnivores had injured or killed livestock and humans in their village in the past year, only $12 \%$ of respondents reported predator conflicts for their household (Append. 1: Table A1.2).

The majority of respondents strongly agreed that adopting agroforestry would provide fuelwood, fodder, and additional income, but that agroforestry would also increase human-wildlife conflicts (Table 2). Over half of respondents did not agree that adopting agroforestry would increase land management costs or require increased labor effort, and they strongly agreed that their family would support their adoption of agroforestry (Table 2). Respondents were most concerned that agroforestry trees would 
Table 2. Percentage of responses for each rank and median responses for five-point Likert scale questions to gauge respondent's attitudes toward modifying land uses, self-efficacy, and social norms

\begin{tabular}{|c|c|c|c|c|c|c|}
\hline & Strongly disagree & Moderately disagree & Neutral & Moderately agree & Strongly agree & Median \\
\hline \multicolumn{7}{|c|}{ Attitude: Do you agree or disagree that land-use change (agroforestry) would... } \\
\hline Provide fuelwood & 10.48 & 0.33 & 2.00 & 16.64 & 70.55 & 5 \\
\hline Provide fodder & 27.64 & 0.67 & 1.84 & 10.05 & 59.80 & 5 \\
\hline Provide additional income & 2.66 & 0.67 & 7.32 & 8.32 & 81.03 & 5 \\
\hline Require more effort for upkeep & 44.09 & 7.15 & 10.98 & 7.65 & 30.12 & 2 \\
\hline Require more expense for upkeep & 54.52 & 5.35 & 10.54 & 6.69 & 22.91 & 1 \\
\hline Cause more conflict with animals & 16.47 & 3.33 & 2.33 & 18.30 & 59.57 & 5 \\
\hline \multicolumn{7}{|c|}{ Self-efficacy: Do you agree or disagree that your ability to adopt agroforestry is constrained by... } \\
\hline Not enough land & 54.58 & 4.16 & 1.50 & 5.66 & 34.11 & 1 \\
\hline No knowledge/training & 29.45 & 4.49 & 1.66 & 9.32 & 55.07 & 5 \\
\hline No irrigation facility & 33.11 & 4.66 & 0.33 & 9.65 & 52.25 & 5 \\
\hline Labor problems & 57.02 & 8.03 & 3.51 & 5.85 & 25.59 & 1 \\
\hline Problems with neighbors & 46.59 & 3.33 & 3.33 & 8.49 & 38.27 & 2 \\
\hline Trees will not grow/fruit & 15.61 & 4.17 & 2.36 & 7.62 & 70.24 & 5 \\
\hline \multicolumn{7}{|c|}{ Social norms: Do you agree or disagree that the following individuals would be supportive of you adopting agroforestry... } \\
\hline Family & 3.34 & 0.00 & 12.21 & 3.34 & 81.10 & 5 \\
\hline Other farmers & 9.69 & 1.44 & 35.73 & 10.77 & 42.37 & 4 \\
\hline Forest department & 14.90 & 1.08 & 37.34 & 4.49 & 42.19 & 3 \\
\hline Village council & 7.79 & 0.56 & 25.79 & 7.05 & 58.81 & 5 \\
\hline
\end{tabular}

${ }^{\top}$ Response 1 - Strongly disagree, 2 - Moderately disagree, 3 - Neutral, 4 - Moderately agree, 5 - Strongly agree

not grow or fruit, and that they did not have the skills or necessary irrigation to successfully implement agroforestry (Table 2).

\section{Stated preference choice experiment}

Only $12 \%$ of respondents rejected all offered agroforestry programs. Most respondents who favored the status quo $(86 \%)$ wanted to continue their current agricultural activities and avoid risks associated with agroforestry. Respondents who rejected agroforestry programs also indicated that the payments were insufficient (37\%), their land was unsuitable for conservation land uses $(35 \%)$, and they were concerned about increased conflicts with wildlife $(18 \%)$.

The coefficients for all variables included in the basic MNL model were significant at $\mathrm{p}<0.01$ or 0.05 (Table 3). On average, respondents preferred to adopt agroforestry (positive coefficient for the ASC). Respondents were less likely to enroll in agroforestry as the amount of land enrolled (negative coefficient for LAND) and the duration of enrollment (negative coefficient for YEARS) increased. The positive coefficient for PAYMENT is consistent with economic theory and indicates that respondents were more likely to adopt agroforestry as the payment per acre per year for enrollment increased.

The basic RPL model (which omitted respondent characteristics) demonstrated that respondents were heterogeneous in their preferences for agroforestry programs (Table 3 ). Respondents preferred to engage in agroforestry relative to the status quo option (positive mean coefficient for the ASC), although the strength of this preference varied across respondents (statistically significant standard deviation coefficient for the ASC). All respondents preferred programs with smaller minimum land requirements (negative mean coefficient for LAND), but again the strength of this preference varied across respondents (statistically significant standard deviation coefficient for LAND). On average, respondents preferred shorter program durations (negative mean coefficient for YEARS), but the magnitude of the standard deviation coefficient demonstrated that a subset of respondents preferred longer programs. Respondents preferred higher payments per acre per year for adopting agroforestry (positive coefficient for PAYMENT).

The two RPL models that allowed coefficients to shift with respondents' demographic, economic, and socio-psychological variables provided greater insights into which characteristics altered their probability of enrolling in agroforestry.

RPL model 1: interaction of demographic and economic variables with LAND and YEARS

In this model, coefficients for LAND and YEARS shifted with respondents' demographic and economic characteristics and provided further evidence that respondents preferred to enroll less land (although the strength of this preference varied across respondents) and that respondents differed in their preferences for program duration (Table 4). Respondents with a high school education and experience of crop raiding by herbivores preferred to enroll a higher percentage of their land $(p<0.05)$. Respondents with higher earnings from agriculture, small families, and higher forest cover surrounding their agricultural land preferred to enroll larger percentages of their land, although these results were only significant at $0.05<\mathrm{p}<0.1$. Respondents with lower agricultural earnings preferred longer programs $(0.05<\mathrm{p}<0.1)$. On average, respondents preferred to enroll in agroforestry programs, and their willingness to enroll increased as PAYMENT increased.

RPL model 2: interaction of socio-psychological variables with the $A S C$

In this model, the ASC shifted with socio-psychological variables and highlighted heterogeneity in respondents' preferences for enrolling in agroforestry programs. Although on average respondents preferred to adopt agroforestry, a subset preferred the status quo (standard deviation coefficient exceeded the mean coefficient for the ASC; Table 5). Respondents who perceived that agroforestry would generate benefits (e.g., fuelwood, fodder) were 
Table 3. Estimated beta coefficients from multinomial logit (MNL) and random parameter logit (RPL) analysis from choice experiment surveys conducted in the buffer area of Pench Tiger Reserve, India in 2018 2019. The MNL model assumes homogeneity in preferences, with a single beta estimate associated with each attribute. The RPL model assumes heterogeneity in preferences; ASC, Land and Year are considered as normally distributed random variables, yielding a distribution of beta estimates, with a mean and variance.

\begin{tabular}{|c|c|c|c|c|c|c|}
\hline \multirow[t]{3}{*}{ Attribute } & \multicolumn{2}{|c|}{ MNL } & \multicolumn{4}{|c|}{ RPL } \\
\hline & \multirow[b]{2}{*}{ Coefficient } & \multirow[b]{2}{*}{ SE } & \multicolumn{2}{|c|}{ Mean } & \multicolumn{2}{|c|}{$\mathrm{SD}$} \\
\hline & & & Coefficient & SE & Coefficient & $\mathrm{SE}$ \\
\hline$\overline{\mathrm{ASC}^{\dagger}}$ & $1.55^{* * *}$ & 0.167 & $4.91 * * *$ & 0.448 & $3.10 * * *$ & 0.343 \\
\hline Land & $-0.04 * * *$ & 0.002 & $-0.09 * * *$ & 0.007 & $0.07 * * *$ & 0.007 \\
\hline Years & $-0.02 * *$ & 0.011 & $-0.05 * *$ & 0.020 & $0.15^{* * *}$ & 0.037 \\
\hline Payment & $0.01 * * *$ & 0.002 & $0.02 * * *$ & 0.004 & & \\
\hline \multicolumn{7}{|l|}{ Model Properties } \\
\hline $\mathrm{AIC} / \mathrm{N}$ & 1.8 & & & 1.53 & & \\
\hline Log-Likelihood & -1615.59 & & & -1371.52 & & \\
\hline $\mathrm{N}$ (observations) & 1800 & & & 1800 & & \\
\hline
\end{tabular}

${ }^{\dagger}$ ASC is an alternative specific constant taking the value 1 if one of the agroforestry programs (Program A or Program B) is chosen and zero otherwise (Program C)

$* * * \mathrm{p}<0.01 ; * * \mathrm{p}<0.05 ; * 0.05<\mathrm{p}<0.1$

more likely to participate $(\mathrm{p}<0.01)$. Respondents who did not view their landholding size as a constraint to agroforestry, and those who were concerned about access to irrigation were also more likely to participate $(\mathrm{p}<0.05$ and $0.05<\mathrm{p}<0.1$, respectively). Perceived support from family members increased the likelihood that respondents would choose to adopt agroforestry $(0.05<\mathrm{p}<0.1)$. Respondents preferred to enroll fewer acres for a shorter duration and preferred a higher annual payment per acre for adopting agroforestry.

We used the best fit MNL model (Append. 1: Table A1.4) to calculate the minimum annual payment per acre (reservation payment) respondents required to enroll in an agroforestry program. The average reservation payment was approximately Rs. $66,000 /$ acre/year (ca. $\$ 940$ USD/acre/year; $\$ 1$ USD = Rs. 70 at the time of survey).

\section{DISCUSSION}

The central Indian landscape supports one of the world's largest tiger populations and is recognized as a global priority landscape for tigers (Wikramanayake et al. 2011). It comprises a network of 16 PAs, some connected by remnant or degraded forests. Apart from the critical role played by PAs in the region, multi-use reserved forests, scrublands, and degraded lands are also highly used by a variety of mammals (Dutta et al. 2015, Srivathsa et al. 2019, Puri et al. 2020). Despite the creation of PAs, the central India landscape has the highest levels of fragmentation due to linear intrusions (roads, railways, and powerlines) with more isolated forest patches relative to other regions in the country (Nayak et al. 2020). A large percentage of the landscape, crucial for maintaining connectivity, is not permeable to animal movement as it is restricted by human land-use, human population, and high density of linear infrastructure (Jayadevan et al. 2020). Even "impediment-free" areas are fragmented and surrounded by areas that inhibit animal movement, e.g., low cover agricultural areas. Several studies focusing on central India recommend maintaining and improving the connectivity of the landscape through restoration of the habitat (Rathore et al. 2012,
Joshi et al. 2013, Yumnam et al. 2014, Dutta et al. 2018). As a significant proportion of the land outside PAs is under private ownership and used for agriculture, long-term persistence of biodiversity in the central Indian landscape is contingent on the way this agricultural matrix is managed, with proper incentives and technical advice.

Restoration of degraded lands has seen some success in India, albeit on communally managed lands with the recognition of community forest resource (CFR) rights under the Forest Rights Act, 2006. Communities have experimented with short-rotation species (bamboo and various fruiting trees), generated incomes through harvest of NTFP, initiated measures for soil and water conservation, imposed restrictions on grazing activities in areas under assisted natural regeneration, and even set aside areas to allow wildlife presence (Agarwal and Saxena 2018). There are few examples of private or NGO-led conservation initiatives, at small spatial scales (Mudappa and Raman 2007). In production landscapes, sustaining biodiversity with agricultural productivity is challenging. Integration of private agricultural lands-a neglected constituency - into India's conservation framework can go a long way in reconciling agriculture, biodiversity, and rural livelihoods (Siebert et al. 2006, Chen et al. 2009, Scriven 2012). To help inform these conservation efforts, we designed a study in which we combined economic models of rational choice (i.e., utility maximization) with broader concepts from social choice theory to examine landowners' willingness to adopt agroforestry in the buffer area of Pench National Park and Tiger Reserve. We focused on how program design and demographic, economic, and socio-psychological variables influenced landowners' willingness to voluntarily enter agroforestry programs.

\section{Program design}

Landowner participation in voluntary conservation programs depends on program design (Ruto and Garrod 2009, EspinosaGoded et al. 2010), in particular whether programs are relevant to local contexts. We found that percentage of land enrolled, duration of enrollment, and payment amount significantly 
Table 4. Estimated beta coefficients for a random parameter logit (RPL) with interaction variables. We allowed Land and Year to be normally distributed random variables. We also included fixed parameters in the model that interacted Land and Year with the demographic and economic characteristics of respondents from choice experiment surveys conducted in the buffer area of Pench Tiger Reserve, India in 2018-2019. The sign of the coefficients indicates the correlation between program attributes and landowner characteristics. Estimates are from the best-fit model based on AIC.

\begin{tabular}{|c|c|c|c|c|}
\hline & \multicolumn{2}{|c|}{ Mean } & \multicolumn{2}{|c|}{ SD } \\
\hline & Coefficient & SE & Coefficient & $\mathrm{SE}$ \\
\hline $\mathrm{ASC}^{\dagger}$ & $4.43 * * *$ & 0.343 & & \\
\hline Land & $-0.16^{* * *}$ & 0.03 & $0.07 * * *$ & 0.006 \\
\hline Years & 0.09 & 0.127 & $0.23 * * *$ & 0.03 \\
\hline Payment & $0.02 * * *$ & 0.004 & & \\
\hline Land X FCOV & $0.03 *$ & 0.017 & & \\
\hline Land X CONF & $0.05 * *$ & 0.018 & & \\
\hline Land X AGE & 0.004 & 0.009 & & \\
\hline Land X EDU1 & 0.01 & 0.012 & & \\
\hline Land X EDU2 & -0.01 & 0.016 & & \\
\hline Land X EDU3 & $0.04 * *$ & 0.017 & & \\
\hline Land X EDU4 & 0.005 & 0.017 & & \\
\hline Land X HHS & $-0.002 *$ & 0.001 & & \\
\hline Land X SIZE & 0.0001 & 0.002 & & \\
\hline Land X AGIN & $0.0003^{*}$ & $2 \mathrm{E}-04$ & & \\
\hline Land X CROP & -0.003 & 0.004 & & \\
\hline Land X SOUR & -0.001 & 0.004 & & \\
\hline Years X FCOV & -0.04 & 0.078 & & \\
\hline Years X CONF & -0.07 & 0.076 & & \\
\hline Years X AGE & -0.04 & 0.039 & & \\
\hline Years X EDU1 & -0.07 & 0.054 & & \\
\hline Years X EDU2 & -0.02 & 0.071 & & \\
\hline Years X EDU3 & -0.09 & 0.081 & & \\
\hline Years X EDU4 & -0.11 & 0.075 & & \\
\hline Years X HHS & 0.002 & 0.006 & & \\
\hline Years X SIZE & 0.01 & 0.008 & & \\
\hline Years X AGIN & $-0.002 *$ & 9E-04 & & \\
\hline Years X CROP & 0.01 & 0.02 & & \\
\hline Years X SOUR & 0.006 & 0.018 & & \\
\hline \multicolumn{5}{|l|}{ Model Properties } \\
\hline $\mathrm{AIC} / \mathrm{N}$ & \multicolumn{4}{|c|}{1.568} \\
\hline Log-Likelihood & \multicolumn{4}{|c|}{-1376.94} \\
\hline
\end{tabular}

FCOV - percentage forest cover in $1 \mathrm{~km}$ of landholding, CONF - dummy variable takes a value of 1 if respondent has experienced conflict with herbivore, AGE - dummy variable takes a value of 1 if respondent is more than 44 years (average age), EDU1 - Education of respondent less than $10^{\text {th }}$ grade, EDU2 - Passed $10^{\text {th }}$ grade, EDU3 - Passed $12^{\text {th }}$ grade,

EDU4 - Graduate and above, HHS - Household size, SIZE - Size of landholding, AGIN - Income from agriculture, CROP - Number of crops grown, SOUR - Number of income sources

${ }^{\dagger}$ ASC is an alternative specific constant taking the value 1 if one of the agroforestry programs (Program A or Program B) is chosen and zero otherwise (Program $\mathrm{C}$ )

$* * * \mathrm{p}<0.01 ; * * \mathrm{p}<0.05 ; * 0.05<\mathrm{p}<0.1$

influenced landowners' willingness to adopt agroforestry. Our finding that respondents preferred to enroll smaller percentages of their land for shorter contract durations (see also Ruto and Garrod 2009) was consistent with comments by several landowners during field research that they would prefer to choose the least restrictive program design ( $25 \%$ land enrolled for 4 years) and if the program proved beneficial (e.g., consistent payments,
Table 5. Estimated beta coefficients for a random parameter logit (RPL) with interactions. We allowed the alternative specific constant (ASC) to be a normally distributed random variable. We also included fixed parameters in the model that interacted the ASC with the socio-psychological characteristics of respondents from choice experiment surveys conducted in the buffer area of Pench Tiger Reserve, India in 2018-2019. The sign of the coefficients indicates the correlation between landowner characteristics and their preferences. Estimates are from the bestfit model based on AIC.

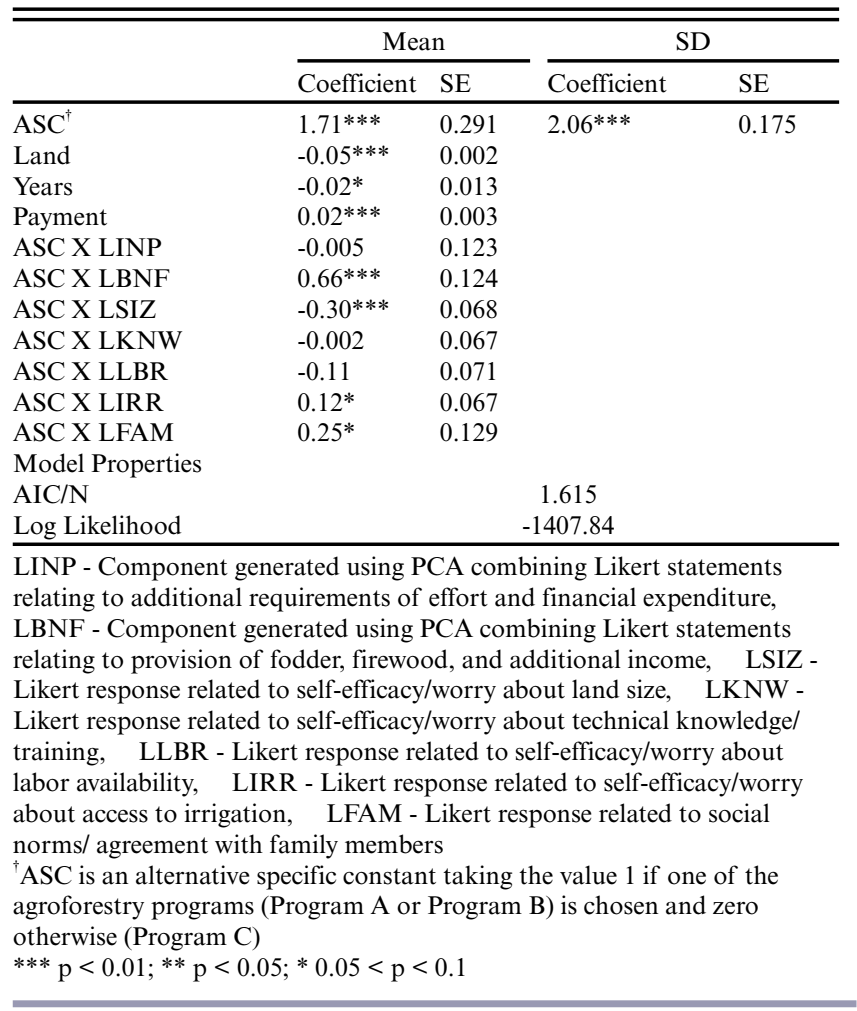

increased access to resources) then they would enroll more land for longer durations in future. Landowners may be skeptical about enrolling land for a long duration due to incomplete knowledge of future benefits, lack of trust that the program will be funded in the medium or long term, and associated risks (e.g., failure of trees to grow and fruit) and costs (e.g., reduced capacity to produce food crops) with transitioning to agroforestry. As there is no existing proof of concept for a voluntary agroforestry program in India, conservation contract designs should allow flexibility in the amount of land enrolled and enrollment duration, provided that the conservation impact of the program is not fundamentally compromised.

Consistent with economic theory, respondents preferred programs with higher payments. Landowners may view conservation payments as a steady, alternative source of income that allows them to reduce risks associated with land-use change, pay household expenses, or invest in off-farm activities (Siebert et al. 2006, Jones et al. 2017). During surveys, respondents indicated that they would invest conservation payments in improved irrigation systems and fencing. Some landowners 
suggested that rather than receiving fixed annual payments, they would prefer larger payments in the initial years to make necessary land-use changes and reduced payments later. Payment structure, frequency of payments, and terms for defaulting and cancellation are important considerations when designing an effective conservation program.

\section{Demographic and economic determinants of program participation}

High surrounding forest cover (which would likely be associated with increased wildlife density) and crop raiding by herbivores increased respondents' willingness to adopt agroforestry. In India, landowners are under-compensated for losses due to crop raiding and often absorb the financial losses themselves (Karanth et al. 2018). A program that provides incentives to adopt agroforestry practices that are not susceptible to crop raiding by herbivores was therefore financially attractive to respondents. Diversification to a multi-crop agroforestry system would also reduce the risks of single crop agriculture. However, adoption of agroforestry systems may result in higher levels of human-wildlife interactions (e.g., livestock predation) within villages. A successful collaborative conservation program will require timely aid to farmers when they face losses from wildlife. Negotiating thresholds or acceptable limits to losses will be challenging but necessary for successful implementation of agroforestry programs.

Landowners with higher education levels are more easily able to engage in the necessary training and process paperwork associated with voluntary conservation programs (Siebert et al. 2006, Peerlings and Polman 2009). We found high school education was the threshold level that encouraged farmers to enroll more land in agroforestry. By contrast, respondents with larger families preferred to enroll less land, which is likely because large rural families in India require more land to meet their subsistence needs and land must be divided amongst multiple male successors (see also Lastra-Bravo et al. 2015 on the role of social networks and successors in the decision to adopt conservation practices). Landowners with higher agricultural earnings preferred to enroll more land in agroforestry perhaps because they could absorb opportunity costs. However, landowners with lower agricultural earnings preferred to enroll for more years, likely to secure payments over a longer period that would allow them to meet their household's financial needs. In contrast to Scriven (2012), we did not find evidence that respondents with larger landholdings were willing to enroll larger portions of their land. Our results also did not support Broch and Vedel's (2012) finding that farmers who rely only on agricultural incomes require higher compensation to enroll in conservation programs.

\section{Socio-psychological determinants of program participation}

Financial incentives may not secure long-term enrollment in conservation programs because they are only an external motivator for voluntary behavioral change (Siebert et al. 2006). We found that payments were not sufficient to persuade landowners who want to remain financially independent by continuing their existing agricultural practices to participate in agroforestry (also see Schenk et al. 2007). The 12\% of respondents who rejected all agroforestry programs were primarily concerned about their ability to meet their household's subsistence needs and ensure their food security. Financial incentives were insufficient to overcome these concerns. Respondents also feared land-use change would result in interference, control, or illegal acquisition of private land by the forest department, which is consistent with previous findings that lack of trust in government impedes voluntary participation in conservation programs (Scriven et al. 2012, Jones et al. 2017).

Inadequate information about the benefits of conservation programs is a barrier to voluntary landowner enrollment in these programs (Kabii and Horwitz 2006). We found that perceived benefits from agroforestry (such as increased availability of fuelwood, fodder, and income), greater self-efficacy, and perceived support of family members for enrollment in conservation programs (social norms) increased respondents' willingness to participate in agroforestry. Self-efficacy, reinforced by availability of resources, training, and social capital, may increase voluntary adoption of agroforestry (McGinty et al. 2008). However, respondents expressed concerns that they had insufficient land to engage in an agroforestry program and lacked the necessary technical knowledge or training to successfully adopt agroforestry. Agricultural systems across India are typically managed by smallholders. Altough this may seem a challenge to reconciling scale-dependent environmental benefits, studies have shown that small farms often have a high capacity to sustain biodiversity and rural livelihoods (Kumaraswamy and Kunte 2013). Interestingly, respondent concerns that agroforestry would fail on their properties because they lack irrigation increased their willingness to adopt agroforestry. Although this initially seems counter-intuitive, some landowners viewed conservation payments as an opportunity to invest in infrastructure (such as wells) on their land. Our results suggest that capacity building is important for ensuring the success of agroforestry development programs. Outreach activities focusing on knowledge sharing and skill development may be crucial in shaping landowner attitudes, alleviating concerns about the viability of conservation actions and improving community-level acceptance of programs (van den Berg et al. 2011, Ardoin et al. 2020).

\section{CONCLUSION}

Over the last five decades, India has conserved its biodiversity through the creation of state-controlled PAs. India's conservation policy has largely ignored the need for a complementary strategy of land sharing in human-dominated landscapes (Fischer et al. 2014, Robbins et al. 2015). Integrated land-use systems would allow conservation and production units to be co-managed for long-term sustainability and improved social welfare (Harvey et al. 2008). However, restoring degraded agricultural landscapes is expensive and typically relies on a mix of government funds, private investments, and NGO support (Clarvis 2014).

Well-designed payments for ecosystem services (PES) may voluntarily engage landowners in land-use practices such as agroforestry that secure biodiversity and ecosystem services (Montagnini and Finney 2011). Within the context of the ongoing agrarian crisis in India, Devi et al. (2017) have argued that PES may also bring farmers out of poverty traps by providing a fixed income. They estimated that the total economic value of the ecosystem services provided by cultivated agroecosystems is approximately Rs. 71,000 (ca. \$1015 USD) per acre per year. We found that farmers in the buffer areas of Pench required an 
average of Rs. 66,000 (ca. \$940 USD) per acre per year to adopt agroforestry, almost equivalant to Devi et al.'s (2017) estimates of conservation benefits that would be generated from agroforestry. Although scholars have critiqued PES approaches (Lele et al. 2010) and have questioned whether India can support the institutional framework necessary for PES implementation (Sharma 2017), there is a consensus that increased farm incomes are urgently needed. Our study demonstrates the potential for an agroforestry-based PES program to be integrated into the country's agroforestry and rural development policy (Siebert et al. 2006, de Koning et al. 2011). However, we do caution that the effectiveness of an agroforestry PES program will likely depend on flexibility of program design and capacity building. Socioeconomic constraints may preclude the enrollment of individuals who do not have the financial means to alter their land management practices, which means that landowners who are most at risk because of poverty may be least likely to engage in an agroforestry PES program. Payment structure may need to vary based on households' financial and resource constraints.

Although it is not immediately apparent how an agroforestry PES program would be financed, our study suggests that landowners would be interested in adopting agroforestry if the program is appropriately designed for social and economic contexts. We envision the application of incentive-based land management practices in fragmented landscapes to restore connectivity and increase the effective size of PAs by improving the ecological quality of surrounding lands. Kshettry et al. (2020) proposed the term "Conservation Compatible Landscape" (CCL) to denote landscapes with high potential for conservation in conjunction with local support. An approach such as ours, which focuses on private landowner willingness to become conservation stewards, can be a means toward realizing these CCLs. We call for a new approach in India that recognizes farmers as stakeholders in conservation and in creating resilient landscapes that support biodiversity and preserve rural livelihoods.

${ }^{1}$ As described by the International Union for Conservation of Nature (IUCN), Protected Areas are "a clearly defined geographical space, recognized, dedicated, and managed, through legal or other effective means, to achieve the long-term conservation of nature with associated ecosystem services and cultural values." They are categorized based on their management objectives, with categories I and II representing areas where human visitation, use, and impacts are strictly controlled and limited.

${ }^{2}$ Tribal communities and other caste groups (including SC and OBC) are part of the hierarchical caste system of India. These communities are listed in a schedule prepared by the Government of India, granting them special status by the Constitution. Reservations in legislature and government jobs are based on this categorization (Bhargava 2010).

${ }^{3}$ A profile (or program) is an alternative that is offered to a person. The program features are called "attributes," and these attributes vary across profiles. For example, a SPCE that focuses on respondents' choice of travel may vary according to the attributes of travel mode (car, train, and bus), travel time, and cost (Hensher et al. 2005).
${ }^{4}$ D-efficiency is related to the statistical efficiency of the design or the attribute combinations that are generated. The best design is the one with the highest D-efficiency, out of a score of 100 (for more details, see Append. 1).

${ }^{5}$ Hypothetical bias occurs when respondents provide hypothetical answers (something they have no intention of doing or are not able to do owing to constraints on their behavior, e.g., budget or labor constraints) when presented with a SPCE.

${ }^{6}$ We note that it is possible to relax the assumption of a fixed parameter on the payment attribute by imposing a lognormal distribution for the coefficient on PAYMENT. However, we found that the random parameters logit model that assumed a fixed parameter for PAYMENT was comparable in terms of model fit to that in which the coefficient on PAYMENT varied. Moreover, the model with a random coefficient for PAYMENT generated inflated measures of respondents' willingness to accept compensation for enrollment in an agroforestry program. Accordingly, we did not relax the assumption of a fixed parameter for PAYMENT.

${ }^{7}$ We included respondents' characteristics in the estimated models as interaction terms (e.g., respondents' characteristics are interacted with program attributes to test for changes in the slope of the estimated function) or as stand-alone independent variables (to test for changes in the intercept of the estimated function).

${ }^{8}$ To reduce dimensionality, we used principal component analysis with varimax rotation to ascertain if individual survey items could be combined to form measures (scores) of respondents' attitudes toward agroforestry. We retained two components with eigenvalues $\geq 1$ and Cronbach's alpha $\geq 0.7$. The two components represented (a) perceived benefits of agroforestry from increased availability of firewood and fodder and increased income levels, and (b) perceived additional expenditures and effort for upkeep/ maintenance required to successfully engage in agroforestry. The scores for the two components were calculated and used as predictor variables in the SPCE models. Based on principal components analysis and Cronbach's alpha, statements that were designed to measure self-efficacy and social norms could not be combined into scores. Accordingly, we included each of these individual items in the SPCE models after testing for collinearity. ${ }^{9}$ For the models we estimated, the alternative specific constant (ASC) took the value 1 if one of the choice scenarios was chosen and zero otherwise. As such, if $\beta_{0}$ (the estimated coefficient for the ASC) is positive, then respondents preferred an agroforestry program over the status quo of no conservation program.

Responses to this article can be read online at: https://www.ecologyandsociety.org/issues/responses. php/12544

\section{Author Contributions:}

Mahi Puri: conceptualization, funding acquisition, methodology, formal analysis, investigation, visualization, writing - original draft, review, and editing; Elizabeth Pienaar: funding acquisition, methodology, validation, writing - review, and editing, supervision; Krithi Karanth: funding acquisition, writing - review, and editing, supervision; Bette Loiselle: funding acquisition, writing - review, and editing, supervision. 


\section{Acknowledgments:}

We thank the Madhya Pradesh Forest Department for providing the necessary research permits to conduct this study. We received funding from National Geographic Society (early career grant), the Rufford Foundation, and DeFries-Bajpai Foundation. The funding agencies had no role in study design, in the collection, analysis, and interpretation of data, and in the decision to submit the article for publication. MP was supported by the University of Florida and KK was supported by Oracle. Centre for Wildlife Studies provided institutional and logistical support. We are grateful to $A$. Adambey, A. Bhatia, A. S. Chauhan, A. Pattnaik, A. Shaikh, C. Hinge, F. Mookherjee, G. Vijayraghavan, N. Bomcher, P. Thakre, $V$. Sabharwal, Y. Khatri for assistance in conducting field surveys.

\section{Data Availability:}

The data that support the findings of this study are available on request from the corresponding author. None of the data are publicly available as they contain information that could compromise the privacy of research participants.

\section{LITERATURE CITED}

Adams, V. M., R. L. Pressey, and N. Stoeck1. 2014. Estimating landholders' probability of participating in a stewardship program, and the implications for spatial conservation priorities. PLoS One 9(6): e97941. https://doi.org/10.1371/journal. pone.0097941

Agarwal, S., and A. K. Saxena. 2018. People's forests: is community forest resource governance the future of India's jungles? Centre for Science and Environment, New Delhi, India.

Andam, K. S., P. J. Ferraro, A. Pfaff, G. A. Sanchez-Azofeifa, and J. A. Robalino. 2008. Measuring the effectiveness of protected area networks in reducing deforestation. Proceedings of the National Academy of Sciences 105(42):16089-16094. https://doi. org/10.1073/pnas.0800437105

Ardoin, N. M., A. W. Bowers, and E. Gaillard. 2020. Environmental education outcomes for conservation: a systematic review. Biological Conservation 241: 108224. https:// doi.org/10.1016/j.biocon.2019.108224

Benjamin, E. O., and J. Sauer. 2018. The cost effectiveness of payments for ecosystem services - smallholders and agroforestry in Africa. Land Use Policy 71:293-302. https://doi.org/10.1016/j. landusepol.2017.12.001

Bhargava, R. 2010. The promise of India's secular democracy. Oxford University Press, Oxford, UK.

Broch, S. W., and S. E. Vedel. 2012. Using choice experiments to investigate the policy relevance of heterogeneity in farmer agrienvironmental contract preferences. Environmental and Resource Economics 51(4):561-581. https://doi.org/10.1007/ s10640-011-9512-8

Bruner, A. G., R. E. Gullison, R. E. Rice, and G. A. B. Fonseca. 2001. Effectiveness of parks in protecting tropical biodiversity. Science 291:125-128. https://doi.org/10.1126/science.291.5501.125
Burnham, K. P., and D. R. Anderson. 2002. Model selection and multimodel inference: a practical information-theoretic approach. Springer, New York, New York, USA.

Chapron, G., P. Kaczensky, J. D. C. Linnell, M. von Arx, D. Huber, H. Andrén, J. V. López Bao, M. Adamec, F. Álvares, O. Anders et al. 2014. Recovery of large carnivores in Europe's modern human-dominated landscapes. Science 346(6216):1517-1519.

Chazdon, R. L. 2017. Landscape restoration, natural regeneration, and the forests of the future. Annals of the Missouri Botanical Garden 102(2):251-257. https://doi.org/10.3417/2016035

Chen, X., F. Lupi, G. He, and J. Liu. 2009. Linking social norms to efficient conservation investment in payments for ecosystem services. Proceedings of the National Academy of Sciences 106 (28):11812-11817. https://doi.org/10.1073/pnas.0809980106

Clarvis, M. H. 2014. Institutions and mechanisms that finance ILM. Pages 19-26 in S. Shames, M. H. Clarvis, and G. Kissinger, editors. Financing strategies for integrated landscape investment, EcoAgriculture Partners, on behalf of the Landscapes for People, Food and Nature Initiative, Washington, D.C., USA.

Cochran, W. G. 1977. Sampling techniques. Third edition. Wiley, New York, New York, USA.

Conradie, B., M. Treurnicht, K. Esler, and M. Gaertner. 2013. Conservation begins after breakfast: the relative importance of opportunity cost and identity in shaping private landholder participation in conservation. Biological Conservation 158:334-341. https://doi.org/10.1016/j.biocon.2012.08.028

DeFries, R., A. Hansen, A. C. Newton, and M. C. Hansen. 2005. Increasing isolation of protected areas in tropical forests over the past twenty years. Ecological Applications 15(1):19-26. https:// doi.org/10.1890/03-5258

de Koning, F., M. Aguiñaga, M. Bravo, M. Chiu, M. Lascano, T. Lozada, and L. Suarez. 2011. Bridging the gap between forest conservation and poverty alleviation: the Ecuadorian Socio Bosque program. Environmental Science and Policy 14:531-542. https://doi.org/10.1016/j.envsci.2011.04.007

Deng, J., P. Sun, F. Zhao, X. Han, G. Yang, and Y. Feng. 2016. Analysis of the ecological conservation behavior of farmers in payment for ecosystem service programs in eco-environmentally fragile areas using social psychology models. Science of the Total Environment 550:382-390. https://doi.org/10.1016/j.scitotenv.2016.01.152

Devi, I. P., L. Kumar L., D. S. Kumar, M. Manjula, P. Mukhopadhyay, D. Sharma, R. Sridhar, and L. Venkatachalam. 2017. Payment for ecosystem services: guaranteed farm income and sustainable agriculture. Economic and Political Weekly 52 (17):12-14.

Dutta, T., S. Sharma, and R. DeFries. 2018. Targeting restoration sites to improve connectivity in a tiger conservation landscape in India. PeerJ 6: e5587. https://doi.org/10.7717/peerj.5587

Dutta, T., S. Sharma, J. E. Maldonado, H. S. Panwar, and J. Seidensticker. 2015. Genetic variation, structure, and gene flow in a sloth bear (Melursus ursinus) meta-population in the Satpura- 
Maikal landscape of central India. PLoS One 10(5): e0123384. https://doi.org/10.1371/journal.pone.0123384

ENVIS Centre on Wildlife and Protected Areas. 2019. Protected areas of India. Wildlife Institute of India, Dehradun, India. [online] URL: http://www.wiienvis.nic.in/Database/Protected_Area_854. $\underline{\operatorname{aspx}}$

Espinosa-Goded, M., J. Barreiro-Hurlé, and E. Ruto. 2010. What do farmers want from agri-environmental scheme design? A choice experiment approach. Journal of Agricultural Economics 61(2):259-273. https://doi.org/10.1111/j.1477-9552.2010.00244.x

Fischer, J., D. J. Abson, V. Butsic, M. J. Chappell, J. Ekroos, J. Hanspach, T. Kuemmerle, H. G. Smith, and H. von Wehrden. 2014. Land sparing versus land sharing: moving forward. Conservation Letters 7(3):149-157. https://doi.org/10.1111/ conl.12084

Flinn, K. M., and M. Vellend. 2005. Recovery of forest plant communities in post-agricultural landscapes. Frontiers in Ecology and the Environment 3(5):243-250. https://doi. org/10.1890/1540-9295(2005)003[0243:rofpci]2.0.co;2

Foley, J. A., R. DeFries, G. P. Asner, C. Barford, G. Bonan, S. R. Carpenter, F. S. Chapin, M. T. Coe, G. C. Daily, H. K. Gibbs, et al. 2005. Global consequences of land use. Science 309 (5734):570-574. https://doi.org/10.1126/science.1111772

Green, W. H. 2016. NLOGIT version 6. Econometric Software Inc., New York, New York, USA.

Harihar, A., D. Veríssimo, and D. C. MacMillan. 2015. Beyond compensation: integrating local communities' livelihood choices in large carnivore conservation. Global Environmental Change 33:122-130. https://doi.org/10.1016/j.gloenvcha.2015.05.004

Harvey, C. A., O. Komar, R. Chazdon, B. G. Ferguson, J. B. Finegan, D. M. Griffith, M. Martínez-Ramos, H. Morales, R. Nigh, L. Soto-Pinto et al. 2008. Integrating agricultural landscapes with biodiversity conservation in the Mesoamerican hotspot. Conservation Biology 22(1):8-15. https://doi.org/10.1111/ j.1523-1739.2007.00863.x

Hensher, D. A., Green, W. H., and J. M. Rose. 2005. Applied choice analysis: a primer. Cambridge University Press. New York, New York, USA. https://doi.org/10.1017/CBO9780511610356

Jayadevan, A., R. Nayak, K. K. Karanth, J. Krishnaswamy, R. DeFries, K. U. Karanth, and S. Vaidyanathan. 2020. Navigating paved paradise: Evaluating landscape permeability to movement for large mammals in two conservation priority landscapes in India. Biological Conservation 247:108613. https://doi.org/10.1016/ j.biocon.2020.108613

Jones, K. W., M. B. Holland, L. Naughton-Treves, M. Morales, L. Suarez, and K. Keenan. 2017. Forest conservation incentives and deforestation in the Ecuadorian Amazon. Environmental Conservation 44(1):56-65. https://doi.org/10.1017/S0376892916000308

Joshi, A., S. Vaidyanathan, S. Mondol, A. Edgaonkar, and U. Ramakrishnan. 2013. Connectivity of tiger (Panthera tigris) populations in the human-influenced forest mosaic of Central India. PloS One 8(11): e77980. https://doi.org/10.1371/journal. pone. 0077980
Kabii, T., and P. Horwitz. 2006. A review of landholder motivations and determinants for participation in conservation covenanting programmes. Environmental Conservation 33:11-20. https://doi.org/10.1017/S0376892906002761

Kamal, S., M. Grodzińska-Jurczak, and G. Brown. 2015. Conservation on private land: a review of global strategies with a proposed classification system. Journal of Environmental Planning and Management 58(4):576-597. https://doi. org/10.1080/09640568.2013.875463

Karanth, K. K., S. Gupta, and A. Vanamamalai. 2018. Compensation payments, procedures and policies towards human-wildlife conflict management: Insights from India. Biological Conservation 227:383-389. https://doi.org/10.1016/j. biocon.2018.07.006

Kashwan, P. 2016. Power asymmetries and institutions: landscape conservation in central India. Regional Environmental Change 16(S1):97-109. https://doi.org/10.1007/s10113-015-0925-8

Knight, A. T., R. M. Cowling, M. Difford, and B. M. Campbell. 2010. Mapping human and social dimensions of conservation opportunity for the scheduling of conservation action on private land. Conservation Biology 24: 1348-58. https://doi.org/10.1111/ j.1523-1739.2010.01494.X

Kshettry, A., S. Vaidyanathan, R. Sukumar, and V. Athreya. 2020. Looking beyond protected areas: identifying conservation compatible landscapes in agro-forest mosaics in north-eastern India. Global Ecology and Conservation 22: e00905. https://doi. org/10.1016/j.gecco.2020.e00905

Kumaraswamy, S., and K. Kunte. 2013. Integrating biodiversity and conservation with modern agricultural landscapes. Biodiversity and Conservation 22:2735-2750. https://doi. org/10.1007/s10531-013-0562-9

Lalani, B., P. Dorward, G. Holloway, and E. Wauters. 2016. Smallholder farmers' motivations for using conservation agriculture and the roles of yield, labour and soil fertility in decision making. Agricultural Systems 146:80-90. https://doi. org/10.1016/j.agsy.2016.04.002

Lastra-Bravo, X.B., C. Hubbard, C., G. Garrod, and A. TolónBecerra. 2015. What drives farmers' participation in EU agrienvironmental schemes?: results from a qualitative meta-analysis. Environmental Science and Policy 54:1-9. https://doi. org/10.1016/j.envsci.2015.06.002

Lele, S., P. Wilshusen, D. Brockington, R. Seidler, and K. Bawa. 2010. Beyond exclusion: alternative approaches to biodiversity conservation in the developing tropics. Current Opinion in Environmental Sustainability 2(1-2):94-100. https://doi.org/10.1016/ j.cosust.2010.03.006

Li, B. V., K. Reardon, N. Satheesh, C. Liu, and K. K. Karanth. 2020. Effects of livestock loss and emerging livestock types on livelihood decisions around protected areas: case studies from China and India. Biological Conservation 248: 108645. https:// doi.org/10.1016/j.biocon.2020.108645

Mace, G. M. 2014. Whose conservation? Changes in the perception and goals of nature conservation require a solid scientific basis. Science 245(6204):1558-1560. 
Mammides, C. 2020. A global analysis of the drivers of human pressure within protected areas at the national level. Sustainability Science 15:1223-1232. https://doi.org/10.1007/s11625-020-00809-7

Margulies, J. D., and K. K. Karanth. 2018. The production of human-wildlife conflict: a political animal geography of encounter. Geoforum 95:153-164. https://doi.org/10.1016/j. geoforum.2018.06.011

McDonald-Madden, E., M. Bode, E. T. Game, H. Grantham, and H. P. Possingham. 2008. The need for speed: informed land acquisitions for conservation in a dynamic property market. Ecology Letters 11(11):1169-1177. https://doi.org/10.1111/ j.1461-0248.2008.01226.x

McFadden, D. 1973. Conditional logit analysis of qualitative choice behavior. Pages 105-142 in P. Zarembka, editor. Frontiers in econometrics. Academic Press, New York, New York, USA.

McGinty, M. M., M. E. Swisher, and J. Alavalapati. 2008. Agroforestry adoption and maintenance: self-efficacy, attitudes and socio-economic factors. Agroforestry Systems 73:99-108. https://doi.org/10.1007/s10457-008-9114-9

Menon, V. 2014. Indian mammals: a field guide. Hatchett India, Gurgaon, India.

Merenlender, A.M., L. Huntsinger, G. Guthey, G., and S. K. Fairfax. 2004. Land trusts and conservation easements: who is conserving what for whom? Conservation Biology 18(1):65-76 https://doi.org/10.1111/j.1523-1739.2004.00401.x

Mittermeier, R. A., W. R. Turner, F. W. Larsen, T. M. Brooks, and C. Gascon. 2011. Global biodiversity conservation: the critical role of hotspots. Pages 3-22 in F. Zachos and J. Habel, editors. Biodiversity hotspots. Springer, Heidelberg, Germany. https://doi.org/10.1007/978-3-642-20992-5_1

Montagnini, F., and C. Finney. 2011. Payments for environmental services in Latin America as a tool for restoration and rural development. Ambio 40(3):285-297. https://doi.org/10.1007/ $\underline{\text { s13280-010-0114-4 }}$

Mora, C., and P. F. Sale. 2011. Ongoing global biodiversity loss and the need to move beyond protected areas: a review of the technical and practical shortcomings of protected areas on land and sea. Marine Ecology Progress Series 434:251-266. https://doi. org/10.3354/meps09214

Mudappa, D., and T. S. Raman. 2007. Rainforest restoration and wildlife conservation on private lands in the Western Ghats. Pages 210-240 in G. Shahabuddin and M. Rangarajan, editors. Making conservation work. Permanent Black, Ranikhet, India.

Nair, P. 2008. Agroecosystem management in the 21st century: it is time for a paradigm shift. Journal of Tropical Agriculture 46:1-12.

Naughton-Treves, L., M. B. Holland, and K. Brandon. 2005. The role of protected areas in conserving biodiversity and sustaining local livelihoods. Annual Review of Environment and Resources 30(1):219-252. https://doi.org/10.1146/annurev.energy.30.050504.164507

Nayak, R., K. K. Karanth, T. Dutta, R. Defries, K. U. Karanth, and S. Vaidyanathan. 2020. Bits and pieces: forest fragmentation by linear intrusions in India. Land Use Policy: 104619. https:// doi.org/10.1016/j.landusepol.2020.104619

Nordén, A., J. Coria, A. M. Jönsson, F. Lagergren, and V. Lehsten. 2017. Divergence in stakeholders' preferences: evidence from a choice experiment on forest landscapes preferences in Sweden. Ecological Economics 132:179-195. https://doi.org/10.1016/j. ecolecon.2016.09.032

Ojeda, D. 2012. Green pretexts: Ecotourism, neoliberal conservation and land grabbing in Tayrona National Natural Park, Colombia. Journal of Peasant Studies 39(2):357-375.

Peerlings, J., and N. Polman. 2009. Farm choice between agrienvironmental contracts in the European Union. Journal of Environmental Planning and Management 52(5):593-612. https:// doi.org/10.1080/09640560902958131

Phalan, B., M. Onial, A. Balmford, and R. E. Green. 2011. Reconciling food production and biodiversity conservation: Land sharing and land sparing compared. Science 333(6047):1289-1291. https://doi.org/10.1126/science.1208742

Pienaar, E. F., L. S. Jarvis, and D. M. Larson. 2014. Using a choice experiment framework to value conservation-contingent development programs: an application to Botswana. Ecological Economics 98:39-48. https://doi.org/10.1016/j.ecolecon.2013.12.015

Pienaar, E. F., J. R. Soto, J. H. Lai, and D. C. Adams. 2019. Would county residents vote for an increase in their taxes to conserve native habitat and ecosystem services? Funding conservation in Palm Beach County, Florida. Ecological Economics 159:24-34. https://doi.org/10.1016/j.ecolecon.2019.01.011

Puri, M., A. Srivathsa, K. K. Karanth, I. Patel, and N. S. Kumar. 2020. The balancing act: maintaining leopard-wild prey equilibrium could offer economic benefits to people in a shared forest landscape of central India. Ecological Indicators 110: 105931. https://doi.org/10.1016/j.ecolind.2019.105931

Ramalingam, R., and P. Dharma Rajan. 2015. Needs for policy on landscape restoration in India. Current Science 108 (7):208-1209.

Rathore, C. S., Y. Dubey, A. Shrivastava, P. Pathak, and V. Patil. 2012. Opportunities of habitat connectivity for Tiger (Panthera tigris) between Kanha and Pench National Parks in Madhya Pradesh, India. PLoS One 7(7): e39996. https://doi.org/10.1371/ journal.pone.0039996

Redpath, S. M., J. D. Linnell, M. Festa-Bianchet, L. Boitani, N. Bunnefeld, A. Dickman, R. J. Gutiérrez, R. J. Irvine, M. Johansson, A. Majić, and B. J. McMahon. 2017. Don't forget to look down - collaborative approaches to predator conservation. Biological Reviews 92(4):2157-2163 https://doi.org/10.1111/ brv. 12326

Robbins, P., A. Chhatre, and K. Karanth. 2015. Political ecology of commodity agroforests and tropical biodiversity. Conservation Letters 8(2):77-85. https://doi.org/10.1111/conl.12169

Roy, P. S., M. D. Behera, M. S. R. Murthy, A. Roy, S. Singh, S. P. S. Kushwaha, C. S. Jha, S. Sudhakar, P. K. Joshi, C. S. Reddy et al. 2015. New vegetation type map of India prepared using satellite remote sensing: comparison with global vegetation maps 
and utilities. International Journal of Applied Earth Observation and Geoinformation 39:142-159. https://doi.org/10.1016/j. jag.2015.03.003

Ruto, E., and G. Garrod. 2009. Investigating farmers' preferences for the design of agri-environment schemes: a choice experiment approach. Journal of Environmental Planning and Management 52(5):631-647. https://doi.org/10.1080/09640560902958172

Schenk, A., M. Hunziker, F. and Kienast. 2007. Factors influencing the acceptance of nature conservation measures - a qualitative study in Switzerland. Journal of Environmental Management 83(1):66-79. https://doi.org/10.1016/j.jenvman.2006.01.010

Scriven, J. 2012. Developing REDD+ policies and measures from the bottom-up for the buffer zones of Amazonian protected areas. Environment, Development and Sustainability 14(5):745-765. https://doi.org/10.1007/s10668-012-9350-Z

Sharma, A. 2017. Payment for ecosystem services. Economic and Political Weekly 52(36):73-74.

Sharma, L. N., and O. R. Vetaas. 2015. Does agroforestry conserve trees? A comparison of tree species diversity between farmland and forest in mid-hills of central Himalaya. Biodiversity and Conservation 24(8):2047-2061. https://doi.org/10.1007/ $\underline{\text { s10531-015-0927-3 }}$

Siebert, R., M. Toogood, and A. Knierim. 2006. Factors affecting European farmers' participation in biodiversity policies. Sociologia Ruralis 46(4):318-340. https://doi.org/10.1111/ j.1467-9523.2006.00420.x

Sinha, B. C., Q. Qureshi, V. K. Uniyal, and S. Sen. 2012. Economics of wildlife tourism - contribution to livelihoods of communities around Kanha tiger reserve, India. Journal of Ecotourism 11(3):207-218. https://doi.org/10.1080/14724049.2012.721785

Srivathsa, A., M. Puri, K. K. Karanth, I. Patel, and N. Samba Kumar. 2019. Examining human-carnivore interactions using a socio-ecological framework: sympatric wild canids in India as a case study. Royal Society Open Science 6(5):182008. https://doi. org/10.1098/rsos. 182008

van den Berg, H. A., S. J. Riley, and S. L. Dann. 2011. Conservation education for advancing natural resources knowledge and building capacity for volunteerism. Society and Natural Resources 24(3):205-220. https://doi.org/10.1080/08941$\underline{920902960404}$

West, P., J. Igoe, and Brockington, D. 2006. Parks and peoples: the social impact of protected areas. Annual Review of Anthropology 35:251-277. https://doi.org/10.1146/annurev. anthro.35.081705.123308

Wikramanayake, E., E. Dinerstein, J. Seidensticker, S. Lumpkin, B. Pandav, M. Shrestha, H. Mishra, J. Ballou, A. J. t. Johnsingh, I. Chestin et al. 2011. A landscape-based conservation strategy to double the wild tiger population. Conservation Letters 4 (3):219-227. https://doi.org/10.1111/j.1755-263X.2010.00162.x
Yumnam, B., Y. V. Jhala, Q. Qureshi, J. E. Maldonado, R. Gopal, S. Saini, Y. Srinivas, and R. C. Fleischer. 2014. Prioritizing tiger conservation through landscape genetics and habitat linkages. PLoS One 9(11): e111207. https://doi.org/10.1371/journal. pone. 0111207 


\section{Appendix 1}

D-efficiency - In the design of experiments, optimal designs are a class of experimental designs that are optimal with respect to some statistical criterion (often related to the variance-covariance matrix). Optimal designs allow parameters to be estimated without bias and with minimum variance. A non-optimal design, in contrast, requires a greater number of experimental runs to estimate the parameters with the same precision as an optimal design. A D-optimal design is a computer generated design and consists of the best subset of experiments selected from the full candidate set. For a given model, $Y=X \beta+\varepsilon$, with a $D$ optimal design, the selected runs maximize the determinant of the information matrix $X^{\prime} X$, resulting in higher precision in the parameter estimates (Atkinson and Donev 1992).

Atkinson, A. C., and A. N. Donev. 1992. Optimum experimental designs. Oxford University Press, Oxford.

\section{Derivation of the reservation payment:}

Respondent $i$ has baseline indirect utility $U_{i 0}$ from their status quo activities (i.e. current farming practices), which is as a function of current household wealth (for example, livestock, cash, and other storables) and current period income:

$U_{i 0}=\gamma \cdot E_{i}+\varepsilon_{i 0}$

where the baseline utility for respondent $i$ is $U_{i 0}, E_{i}$ is the households's status quo wealth and money income, $\varepsilon_{i 0}$ is a random error, and $\gamma$ is a parameter to be estimated. If respondent $i$ elects to enroll in agroforestry program $j$ then their indirect utility function is:

$U_{i j}=V_{i j}+\varepsilon_{i j}=\mathbf{X}_{\mathrm{ij}}^{\prime} \boldsymbol{\beta}+\gamma \cdot\left(E_{i}+\right.$ Payment $\left._{i j}\right)+\varepsilon_{i j}$

where the utility derived from enrolling in agroforestry program $j$ is $U_{i j}$, $\mathbf{X}_{\mathbf{i j}}$ is a vector of the non-monetary attributes of the program (e.g. land to be enrolled, duration of the program), Payment $_{\mathrm{ij}}$ is the annual payment per acre for enrollment in program $j, \varepsilon_{i j}$ is a random error, and $\boldsymbol{\beta}$ is a vector of parameters to be estimated. Respondent $i$ 's characteristics enter the model as shifters on the $\boldsymbol{\beta}$ parameters.

The probability that respondent $i$ chooses to enroll in agroforestry program $j$ (i.e. they respond that Yes they would prefer to enroll in that program) is:

$\operatorname{Pr}($ Yes $)=\operatorname{Pr}\left(U_{i j}>U_{i 0}\right)=\operatorname{Pr}\left(\Delta \varepsilon_{i j}<\Delta V_{i j}\right)$

where $\Delta \varepsilon_{i j}=\varepsilon_{i 0}-\varepsilon_{i j}$ is the difference in errors and

$\Delta V_{i j}=V_{i j}-V_{i 0}=\mathbf{X}_{\mathrm{ij}}^{\prime} \boldsymbol{\beta}+\gamma \cdot\left(E_{i}+\right.$ Payment $\left._{i j}\right)-\gamma \cdot E_{i}=\mathbf{X}_{\mathrm{ij}}^{\prime} \boldsymbol{\beta}+\gamma \cdot$ Payment $_{i j}$ 
is the utility difference between enrolling in agroforestry program $j$ and not enrolling in the program (i.e., remaining at status quo). The reservation price at which respondent $i$ will choose to enroll in agroforestry program $j$ is the minimum payment (Payment $t_{i j}$ ) that respondent $i$ will accept for enrollment in the program, and is defined implicitly by the utility difference being zero:

$\mathbf{X}_{\mathbf{i j}}^{\prime} \boldsymbol{\beta}+\gamma \cdot$ Payment $_{i j}=0$

The reservation price can thus be solved for as:

reservation price $=-\frac{\mathbf{X}_{\mathrm{ij}}^{\prime} \boldsymbol{\beta}}{\gamma}$

Figure A1.1: Photographs used to illustrate the (a) current and (b) the envisioned state of the land. These photographs were shown along with a detailed explanation of the kind of agroforestry practices that the landowner could potentially undertake. Photographs are for representation purpose only.
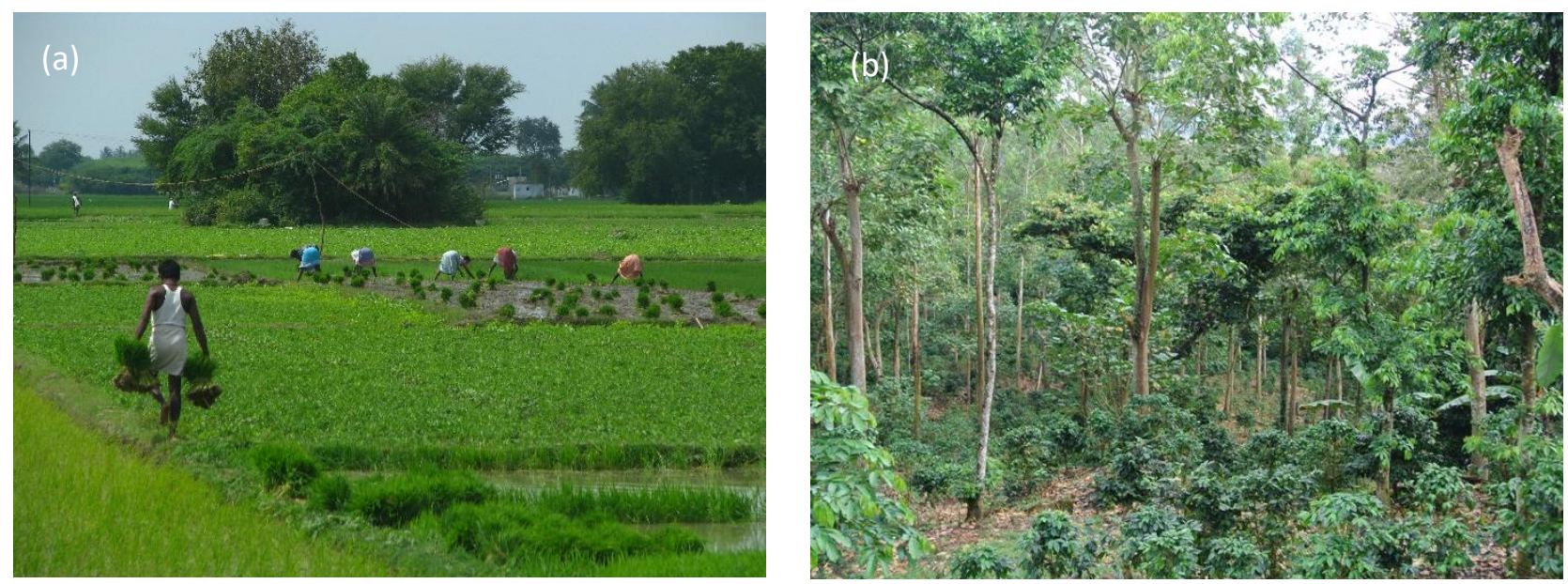

Photo credits:

Image (a) - https://www.flickr.com/photos/mckaysavage/2230560278

Image (b) - C Watson (https://blog.worldagroforestry.org/index.php/2016/05/23/innicaragua-a-staggering-diversity-and-density-of-trees-on-farms/) 
Table A1.1: Description of demographic, economic and socio-psychological variables and the parameters they interacted with in the two RPL models.

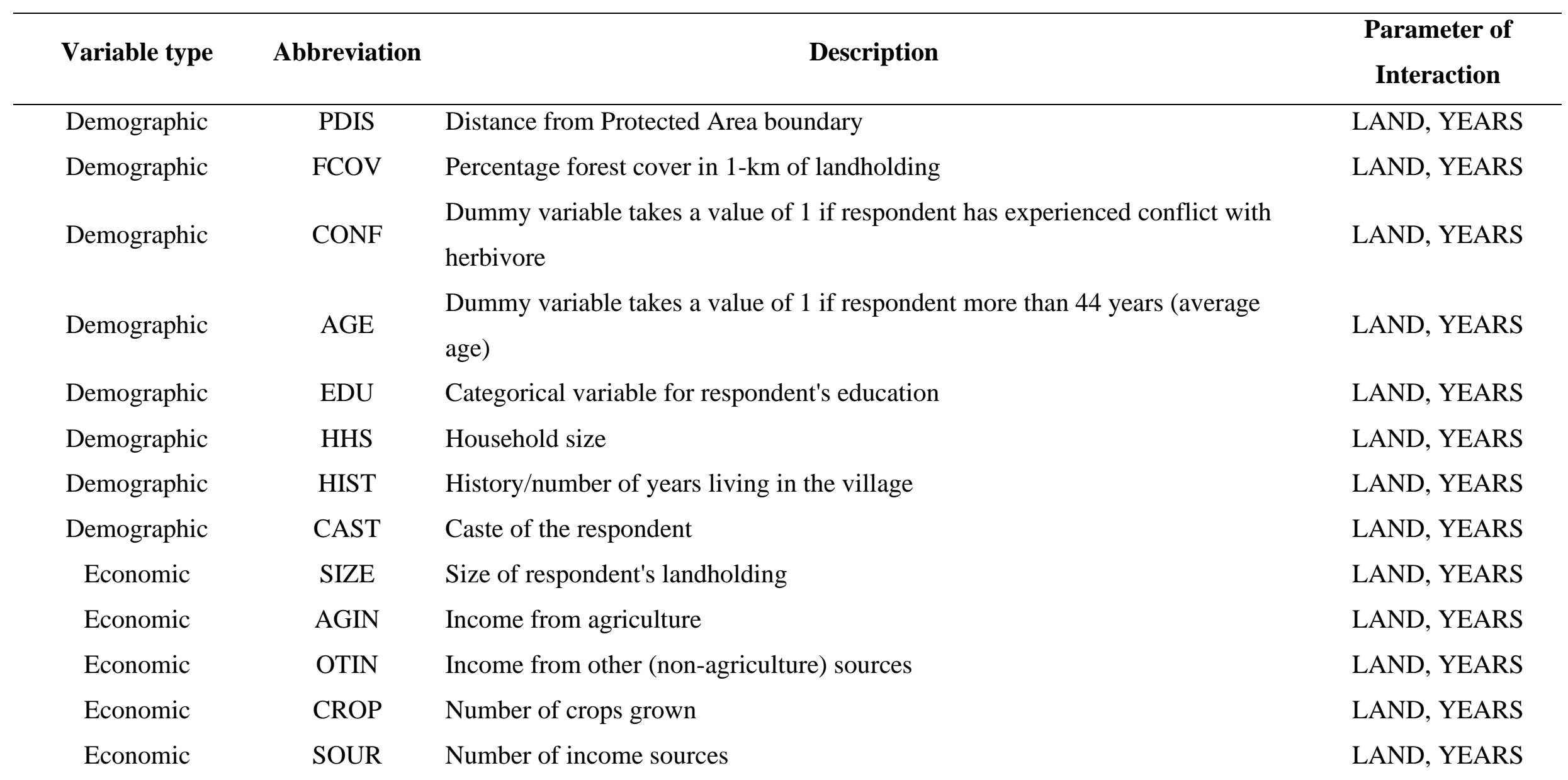




\begin{tabular}{|c|c|c|c|}
\hline Socio-psychological & LINP & $\begin{array}{l}\text { Component generated using PCA combining Likert statements relating to } \\
\text { additional requirements of effort and financial expenditure }\end{array}$ & ASC \\
\hline Socio-psychological & LBNF & $\begin{array}{l}\text { Component generated using PCA combining Likert statements relating to } \\
\text { provision of fodder, firewood, and additional income }\end{array}$ & ASC \\
\hline Socio-psychological & LHWC & Likert statements relating to increase in conflict with animals & ASC \\
\hline Socio-psychological & LSIZ & Likert response related to self-efficacy/worry about land size & ASC \\
\hline Socio-psychological & LKNW & Likert response related to self-efficacy/worry about technical knowledge/training & ASC \\
\hline Socio-psychological & LLBR & Likert response related to self-efficacy/worry about labor availability & ASC \\
\hline Socio-psychological & LIRR & Likert response related to self-efficacy/worry about access to irrigation & ASC \\
\hline Socio-psychological & LNBR & Likert response related to self-efficacy/worry about problems with neighbors & ASC \\
\hline Socio-psychological & LSUC & Likert response related to self-efficacy/worry about trees not growing or fruiting & ASC \\
\hline Socio-psychological & LFAM & Likert response related to social norms/ agreement with family members & ASC \\
\hline
\end{tabular}


Table A1.2: Demographic and socio-economic characteristics of respondents $(\mathrm{N}=602)$

\begin{tabular}{lll}
\hline Characteristics & Sub-characteristics & Details
\end{tabular}

Villages sampled

90

Number of people in $\mathrm{HH}^{1}$

(Average/HH)

\section{5}

\begin{tabular}{|c|c|c|c|}
\hline & & Respondent & Household \\
\hline \multirow[t]{2}{*}{ Gender } & Male & $98 \%$ & $43 \%$ \\
\hline & Female & $2 \%$ & $57 \%$ \\
\hline \multirow[t]{4}{*}{ Age } & $<18$ & NA & $30 \%$ \\
\hline & $18-40$ & $44 \%$ & $46 \%$ \\
\hline & $41-65$ & $51 \%$ & $19 \%$ \\
\hline & $>65$ & $5 \%$ & $5 \%$ \\
\hline \multirow[t]{5}{*}{ Education } & illiterate & $13 \%$ & $19 \%$ \\
\hline & $<10^{\text {th }}$ grade & $53 \%$ & $50 \%$ \\
\hline & $10^{\text {th }}$ grade & $12 \%$ & $10 \%$ \\
\hline & $12^{\text {th }}$ grade & $10 \%$ & $6 \%$ \\
\hline & Graduate and above & $12 \%$ & $14 \%$ \\
\hline \multirow[t]{4}{*}{ Caste } & Scheduled Tribe & \multicolumn{2}{|c|}{$56 \%$} \\
\hline & Scheduled Caste & \multicolumn{2}{|c|}{$6 \%$} \\
\hline & Other Backward Class & \multicolumn{2}{|c|}{$31 \%$} \\
\hline & General & \multicolumn{2}{|c|}{$7 \%$} \\
\hline \multirow[t]{4}{*}{ History of living in village } & $0-5$ years & \multicolumn{2}{|c|}{0} \\
\hline & $6-19$ years & \multicolumn{2}{|c|}{$1 \%$} \\
\hline & 20-49 years & \multicolumn{2}{|c|}{$11 \%$} \\
\hline & $>50$ years & \multicolumn{2}{|c|}{$88 \%$} \\
\hline Livestock ownership - & Cows & \multicolumn{2}{|c|}{$4.79(0-34)$} \\
\hline \multirow[t]{3}{*}{ Average/HH (min-max) } & Buffaloes & \multicolumn{2}{|c|}{$1.27(0-32)$} \\
\hline & Goat & \multicolumn{2}{|c|}{$1.55(0-27)$} \\
\hline & Total & \multicolumn{2}{|c|}{$7.61(0-66)$} \\
\hline \multirow[t]{4}{*}{ Landholding size } & $<3$ acres & \multicolumn{2}{|c|}{$4 \%$} \\
\hline & 3-5 acres & \multicolumn{2}{|c|}{$38 \%$} \\
\hline & 6-10 acres & \multicolumn{2}{|c|}{$30 \%$} \\
\hline & $>10$ acres & \multicolumn{2}{|c|}{$28 \%$} \\
\hline
\end{tabular}


Number of crops grown -

Average/HH (min-max)

Annual Agricultural Revenue ${ }^{2}$ -

Rs. 1,50,000 ( USD 2142)

Median/HH (min-max)

(Rs. 10,000 - Rs. 30,00,000)

Non-agricultural Income Sources

Daily wage labor

$44 \%$

Dairy

$9 \%$

NTFP

$56 \%$

Non-service jobs ${ }^{3}$

$3 \%$

Service jobs ${ }^{4}$

$26 \%$

Business $^{5}$

$21 \%$

Pension

$11 \%$

Number of non-agricultural

income sources - Average/HH

$2(0-5)$

(min-max)

Annual Non-agricultural Income -

Median/HH

Carnivore interaction (7 species $\left.^{6}\right)$

$\mathrm{LP}+\mathrm{HI}+\mathrm{HD}$ (personal loss)

Rs. 51,200 ( USD 730)

$\mathrm{LP}+\mathrm{HI}+\mathrm{HD}$ (in village)

$12 \%$

$70 \%$

Herbivore interaction (crop

3 species

$32 \%$

raiding) - number of species

2 species

$32 \%$

named in top 3 problem animals

1 species

$29 \%$

None

$7 \%$

${ }^{1} \mathrm{HH}$ - household

${ }^{2}$ Rs. - Indian Rupees (1 USD = Rs. 70)

${ }^{3}$ Non-service jobs including employment in factory or as truck driver

${ }^{4}$ Service jobs including employment as teacher, in tourism sector or government

${ }^{5}$ Business including own shop, contractor, mill

${ }^{6}$ Carnivores including tiger, leopard, bear, wolf, wild dog, jackal, fox; LP = Livestock predation, $\mathrm{HI}$ - human injury, HD - human death 
Table A1.3: Descriptive statistics for local context regarding rainfall trends, emigration, forest dependence, and perceptions about living adjacent to forest, based on questionnaire surveys $(n=602)$ in the buffer areas of Pench Tiger reserve, Madhya Pradesh, India.

\begin{tabular}{|c|c|c|}
\hline Questions regarding local context & Categories & Percentage \\
\hline $\begin{array}{l}\text { Have you experienced changes in } \\
\text { rainfall pattern over the last } 3 \text { years }\end{array}$ & $\begin{array}{l}\text { No change } \\
\text { Decreased } \\
\text { Increased } \\
\text { Erratic }\end{array}$ & $\begin{array}{c}3.32 \\
74.92 \\
0.50 \\
18.44\end{array}$ \\
\hline $\begin{array}{l}\text { Has the change in rainfall patterns } \\
\text { resulted in increase or decrease in } \\
\text { your agricultural income }\end{array}$ & $\begin{array}{l}\text { No change } \\
\text { Decreased } \\
\text { Increased }\end{array}$ & $\begin{array}{c}4.10 \\
95.56 \\
0.34\end{array}$ \\
\hline $\begin{array}{l}\text { What would you like for the future } \\
\text { of your family/children }\end{array}$ & $\begin{array}{l}\text { Stay here and continue farming } \\
\text { Stay here but not farm } \\
\text { Move to city or town for job } \\
\text { They can decide for themselves }\end{array}$ & $\begin{array}{c}22.84 \\
4.40 \\
60.41 \\
12.69\end{array}$ \\
\hline $\begin{array}{l}\text { What resources do you obtain from } \\
\text { the forest }\end{array}$ & $\begin{array}{l}\text { Firewood } \\
\text { Fodder } \\
\text { NTFP } \\
\text { Livestock grazing } \\
\text { Other }\end{array}$ & $\begin{array}{c}62.46 \\
2.99 \\
49.17 \\
49.38 \\
0.33\end{array}$ \\
\hline Do you like living near a forest & $\begin{array}{l}\text { No } \\
\text { Yes } \\
\text { Neutral }\end{array}$ & $\begin{array}{c}5.81 \\
69.93 \\
24.25\end{array}$ \\
\hline $\begin{array}{l}\text { Reasons for liking living near } \\
\text { forest }\end{array}$ & $\begin{array}{l}\text { Ancestral ties, affiliation to land and } \\
\text { community support } \\
\text { Resource availability } \\
\text { Ecological and aesthetic value of forests } \\
\text { Job in tourism sector } \\
\text { Job in forest dept } \\
\text { Other reasons }\end{array}$ & $\begin{array}{c}82.01 \\
36.86 \\
84.30 \\
5.64 \\
0.88 \\
7.94\end{array}$ \\
\hline $\begin{array}{l}\text { Reasons for disliking living near } \\
\text { forest }\end{array}$ & $\begin{array}{l}\text { Crop raiding by herbivores } \\
\text { Livestock loss to carnivores } \\
\text { Low standards of education } \\
\text { Poor healthcare } \\
\text { Limited job opportunities } \\
\text { Overcrowding due to tourism } \\
\text { Other reasons }\end{array}$ & $\begin{array}{c}87.36 \\
23.08 \\
30.22 \\
35.71 \\
20.33 \\
1.10 \\
21.43 \\
\end{array}$ \\
\hline
\end{tabular}


Table A1.4: Estimated beta coefficients from multinomial logit (MNL) model incorporating landowner characteristics of respondents from choice experiment surveys conducted in the buffer area of Pench Tiger Reserve, India in 2018-19. Estimates are from the best-fit model based on AIC.

\begin{tabular}{lcc}
\hline Attribute & \multicolumn{2}{c}{ MNL } \\
\cline { 2 - 3 } & Coefficient & SE \\
\hline ASC $^{\dagger}$ & $1.18^{* * *}$ & 0.07 \\
Land & $-0.04 * * *$ & 0.002 \\
Year & -0.002 & 0.01 \\
Payment & $0.02^{* * *}$ & 0.002 \\
& & \\
BFCOV & $0.11^{*}$ & 0.06 \\
BCONF & $0.14^{* *}$ & 0.06 \\
& & \\
Model Properties & & \\
\hline AIC/N & \multicolumn{2}{c}{1.126} \\
Log-Likelihood & \multicolumn{2}{c}{-3035.44} \\
\hline
\end{tabular}

BFCOV - binary variable with $1=$ more than $25 \%$ forest cover in the $1-\mathrm{km}$ buffer of landholding

BCONF - binary variable with $1=$ conflict (crop loss) with two or more herbivores

${ }^{\dagger}$ ASC is an alternative specific constant taking the value 1 if one of the agroforestry programs (Program A or Program B) is chosen and zero otherwise (Program C)

$* * * \mathrm{p}<0.01 ; * * \mathrm{p}<0.05 ; * 0.05<\mathrm{p}<0.1$ 